REVISTA DE DERECHO UNED, núm. 3, 2008

\title{
LA REFORMA DE LOS DELITOS CONTRA LA SEGURIDAD VIAL
}

\author{
Alfonso Serrano Gómez y Alfonso Serrano Maíllo \\ Profesores de Derecho penal y Criminología
}

Resumen: Debido a las relativamente altas tasas de fallecimientos y lesiones en el ámbito del tráfico de vehículos a motor, el legislador español ha reformado el Código penal, de este modo confiando en un efecto preventivo. Siguiendo la tendencia de los últimos años, la Reforma tipifica nuevas conductas como delitos e incrementa las penas para muchos delitos. No hace falta decir que este es un ulterior ejemplo de la expansión del Derecho penal, tal y como se ha encontrado en otros sitios. Entre las potenciales causas puede citarse una deficiente política criminal. En parte, ello es el resultado de la tradición antiempírica de las autoridades españolas, la cual ha impedido investigaciones sólidas sobre las causas de tasas de fallecimientos y lesiones en el ámbito del tráfico de vehículos a motor, así como una evaluación científica de los programas de control y prevención. Un más eficiente control del tráfico rodado, mejoras en las carreteras y mecanismos de prevención situacional tales como limitadores de velocidad en los propios vehículos parecen políticas de lejos más prometedoras (e imaginativas) que una nueva expansión de las leyes penales.

Palabras clave: Delitos contra la seguridad en el tráfico. Delitos contra la seguridad en el tráfico y puesta en peligro concreto. Conducción bajo los efectos del alcohol o las drogas. Derecho penal y Derecho administrativo. Política criminal.

Abstract: Due to the high rates of traffic casualties and injuries, the Spanish legislator has reformed the Criminal Law, thus expecting a deterrent effect. Following the trend of last years, the Reform introduces new actions as crimes and increases the penalties of many cri- 
mes. Needless to say, this is a further example of the expansion of the Criminal laws, as has been found in other places. Among potential causes, a deficient criminal policy can be cited. In part, it is also a result of the anti-empirical tradition of the Spanish authorities, one that has prevented sound research on the causes of the rates of traffic casualties and injuries, as well as sound evaluation of the programs for its control and prevention. A better control of the traffic, improvements in the roads and situational prevention mechanisms such as speed-limitation devices for cars seem far more promising (and imaginative) policies than a new expansion of Criminal laws.

Key words: Reckless driving. Reckless driving and personal risk. Driving under the influence of alcohol or drugs. Criminal and Administrative Law. Criminal policy.

Por LO 15/2007 de 30 de noviembre se modifica el Código penal en materia de seguridad vial. El capítulo IV, del Título XVII, del Libro II, figura ahora bajo la rúbrica «De los delitos contra la seguridad vial», que antes de la reforma era «De los delitos contra la seguridad del tráfico». Siguiendo en política criminal la tendencia de los últimos gobiernos, con la reforma se endurecen las penas y se introducen nuevos tipos penales. Se pretende que la reforma tenga efectos preventivos ante el elevado número de accidentes de tráfico, con resultado de muerte o lesiones. Según los datos que recogen las Memorias de la Fiscalía General del Estado en general los delitos contra la seguridad del tráfico han disminuido en los últimos años, de lo que puede deducirse que no era necesaria la reforma, o por lo menos la agravación de las penas en los delitos cuya tendencia era a la baja ${ }^{1}$, aunque hay quien opina lo contrario ${ }^{2}$. Un mayor control en las infracciones admi-

1 Según las Memorias de la Fiscalía General del Estado los procedimientos iniciados por presuntos delitos por conducción bajo la influencia de bebidas alcohólicas o drogas tóxicas fueron: en 1997 (58.540), 1998 (42.929), 1999 (47.752), 2000 (41.447), 2001 (40.426), 2002 (46.489), 2003 (43.086), 2004 (38.919), 2005 (30.246), 2006 (18.649). Por conducción temeraria: en 1997 (10.3420), 1998 (8.216), 1999 (5.113), 2000 (3.100), 2001 (3.027), 2002 (4.380), 2003 (1.914), 2004 (1.641), 2005 (1.187), 2006 (2.620). Riesgo para la circulación: 1997 (15.965), 1998 (7.736), 1999 (9.747), 2000 (7.998), 2001 (5.599), 2002 (1.449), 2003 (1.712), 2004 (1.770), 2005 (1.187), 2006 (1.273). Conducción con desprecio para la vida de los demás: 1997 (5.692) (sic), 1998 (1.484), 1999 (65), 2000 (58), 2001 (155), 2002 (56), 2003 (63), 2004 (91), 2005 (178), 2006 (83). Negativa a realizar las pruebas de alcoholemia: $1997(702), 1998(8.216)$ (sic), 1999 (838), 2000 (854), 2001 (756), 2002 (1.635), 2003 (1.669), 2004 (2.015), 2005 (954), 2006 (704). En los datos anteriores se aprecia una diferencia notable en las secuencias de la mayoría de los delitos, lo que no parece lógico.

2 Vid. Villalba Carrasouilla, F.J., "El endurecimiento de las penas de los delitos de tráfico como medida de mejora de la siniestralidad", en Mir Puig y Corcoy Bidasolo (directores), Seguridad vial y derecho penal, Barcelona, 2008, págs. 324 y ss. 
nistrativas posiblemente tenga mayores efectos que la agravación de las penas, así como instalar un limitador de velocidad en los vehículos. Desde que se estableció la pérdida de puntos ${ }^{3}$ que afectan a la retirada del permiso de conducir ${ }^{4}$ se aprecia una notable disminución en casi todos los delitos . En todo caso son muchos los accidentes de tráfico constitutivos de falta que no se persiguen por no denunciar la parte perjudicada o por acuerdo o renuncia ${ }^{5}$. Debido a las compañías de seguros muchas de las infracciones de tráfico que pueden ser constitutivas de delito o falta, por acuerdo de las partes, no terminan en la vía penal, lo que es importante a efectos de la carga que supondría para la administración de justicia ${ }^{6}$.

3 La Ley 17/2005, de19 de julio (BOE núm. 172, del 20), regula el permiso y la licencia de conducción por puntos y se modifica el texto articulado de la ley sobre tráfico, circulación de vehículos a motor y seguridad vial. El párrafo último del artículo 60 de esta Ley establece que «la vigencia del permiso o la licencia de conducción estará condicionada a que su titular no haya perdido su asignación total de puntos, que será de 12 puntos». El anexo II se ocupa de las «infracciones que llevan a aparejada la pérdida de puntos». Cabe destacar: 1 . Por conducir con una tasa de alcohol superior a la reglamentaria establecida de 4 a 6 puntos. 2 . Conducir bajo los efectos de estupefacientes, psicotrópicos, estimulantes y otras sustancias de efectos análogos (6 puntos). 3. Incumplir la obligación de someterse a las pruebas de detención del grado de alcoholemia, de estupefacientes, psicotrópicos, estimulantes y otras sustancias de efectos análogos ( 6 puntos). El anexo recoge hasta 27 infracciones por las que se pueden perder puntos, por exceso de velocidad también la pérdida de puntos puede llegar hasta 6. Este sistema del carnet por puntos ya se había implantado en otros países como Italia y Francia donde se habían obtenido buenos resultados en materia de prevención de accidentes de tráfico con resultado de muerte o lesiones.

${ }^{4}$ En los delitos contra la seguridad vial donde se contempla la pena de privación del derecho a conducir vehículos a motor y ciclomotores no lleva consigo la pérdida de puntos. No obstante, la Ley 17/2005 incorpora una disposición adicional, la decimotercera a la Ley sobre tráfico, circulación de vehículos a motor y seguridad vial aprobado por el Real Decreto Legislativo 339/1990, de 2 de marzo, cuyo contenido es el que sigue: «Efectos administrativos de las condenas penales que conlleven la privación del derecho a conducir. El titular del permiso o licencia de conducción que haya sido condenado por sentencia firme por la comisión de un delito castigado con la privación del derecho a conducir un vehículo a motor o ciclomotor, para volver a conducir, deberá acreditar el haber superado con aprovechamiento el curso de reeducación y sensibilización vial al que hace referencia el primer párrafo del artículo 63.7».

${ }_{5}$ La Memoria de la Fiscalía General del Estado de 2005 recoge en su pág. 519: «Los accidentes de tráfico constitutivos de falta (art. 621), sólo son perseguibles previa denuncia de la persona agraviada o su representante legal. Ello ha llevado a que el procedimiento iniciado por el parte de lesiones o el atetado de la policía judicial se archive en los Juzgados hasta que se produzca la denuncia dentro del plazo legal, y producida la denuncia, se celebrará el juicio de faltas, salvo cuando las partes perjudicadas llegan a un acuerdo, que producirá el archivo del juicio por renuncia del perjudicado al ejercicio de la acción penal».

${ }_{6}$ La Memoria de la Fiscalía General del Estado de 2005, en pág. 531, tras ocuparse del papel de las compañías de seguros como responsables civiles subsidiarios en casos de seguro obligatorio o voluntario recoge: $« 10^{\circ}$ Que la gran mayoría de los casos de imprudencia cometidas en el ámbito de la circulación de vehículos a motor se va- 
Ilícito penal e ilícito administrativo. En estos delitos hay supuestos en los que coincide el texto de la legislación vial y el Código penal, por lo que puede resultar complicado determinar cuándo estamos en vía administrativa o vía penal ${ }^{7}$. Por ejemplo, en el art. 65.5 , a) de la Ley de Tráfico $^{8}$ se contempla como infracción muy grave, cuando no sean constitutivas de delito, «... la conducción bajo los efectos de estupefacientes, psicotrópicos, estimulantes y cualquier otra sustancia de efectos análogos». En el art. 379.2 se castiga al «que condujere un vehículo de motor o ciclomotor bajo la influencia de drogas tóxicas, estupefacientes, sustancias psicotrópicas ...». Hay otros supuestos en los que se plantean situaciones similares entre ilícito administrativo e ilícito penal ${ }^{9}$.

Principio non bis in idem. En la legislación de tráfico, circulación de vehículos y seguridad vial se contemplan conductas cuya sanción es administrativa. Sin embargo, algunas de estas conductas pasan a ser constitutivas de delito cuando reúnen los requisitos establecidos en el Código penal. Estos comportamientos no pueden ser sancionados dos veces, es decir en vía penal y administrativa, por impedirlo el principio non bis in idem ${ }^{10}$. La jurisdicción penal es preferente a la vía adminis-

loran como leves. $2 .^{\circ}$ En consecuencia, tales conductas determinan la incoación de juicios de faltas. $3 .^{\circ}$ La apreciación de la existencia de un delito queda limitada a aquellos casos en los que, o bien existe una concurrente conducción bajo la influencia de bebidas alcohólicas, o bien la conducta imprudente es merecedora, por la causa o por el resultado, de un especial reproche. $4 .^{\circ} \mathrm{Y}$, por último, que el hecho de que una imprudencia que ocasiona lesiones o incluso la muerte de una persona dé lugar, tan sólo, a un juicio de faltas, supone en la práctica, como es bien sabido, que no exista un verdadero castigo o sanción de esa conducta, dado que en numerosas ocasiones y a raíz del pago de las responsabilidades civiles, se produce la retirada de la denuncia (necesaria para proceder -art. 621.6 del Código Penal? lo cual supone, por sí mismo, un plus de penosidad para el perjudicado), y en los casos en que efectivamente se produce la celebración del juicio oral y el dictado de sentencias condenatoria, las multas impuestas suelen ser de escasa cuantía».

7 La Consulta de la Fiscalía General del Estado 1/2006, de 21 de abril, se ocupa de la «calificación jurídico-penal de la conducción de vehículos de motor a velocidad extremadamente elevada». Se publica en la Memoria de la FGE de 2007, I, págs. 919 y ss. En págs. 928 y ss. trata del ilícito penal e infracción administrativa y del principio non bis in idem, en supuestos de conducción manifiestamente temeraria, con peligro para la vida o integridad de las personas.

8 Real Decreto Legislativo 339/1990. Vid. supra nota 4.

9 En el art. 65.5,b) se recoge como falta muy grave, cuando no sea constitutiva de delito, «incumplir la obligación de todos los conductores de vehículos de someterse a las pruebas que se establezcan para la detección de posible intoxicaciones de alcohol, estupefacientes, psicotrópicos, estimulantes y otras sustancias análogas...». En el art. 383 del Código penal se castiga al "conductor que, requerido por un agente de la autoridad, se negare a someterse a las pruebas legalmente establecidas para la comprobación de las tasas de alcoholemia y la presencia de las drogas tóxicas, estupefacientes y sustancias psicotrópicas a que se refieren los artículos anteriores».

${ }^{10}$ La sent. del TC 2/2003, de 16 de enero, recoge: " (...) ambas infracciones, administrativa y penal, comparte un elemento nuclear común -conducir un vehículo de 
trativa, siempre que la conducta del autor pueda ser objeto de infracción penal. Así se contempla en el art. 74 de la Ley sobre tráfico ${ }^{11}$.

El bien jurídico protegido en estos delitos, con carácter general, es la seguridad vial para proteger la vida y la integridad física de las personas.

\section{CONDUCCIÓN DE UN VEHÍCULO DE MOTOR O CICLOMOTOR A VELOCIDAD EXCESIVAMENTE SUPERIOR A LA PERMITIDA}

Se castiga en el 379.1 al «que condujere un vehículo de motor o un ciclomotor a velocidad superior en sesenta kilómetros por hora en vía urbana o en ochenta kilómetros por hora en vía interurbana a la permitida reglamentariamente».

Pena: Prisión de tres a seis meses o multa de seis a doce meses y trabajos en beneficio de la comunidad de treinta y uno a noventa días y en cualquier caso, a la privación del derecho a conducir vehículos a motor y ciclomotores por tiempo superior a uno y hasta cuatro años.

\footnotetext{
motor habiendo ingerido alcohol, superando las tasas reglamentariamente determinadas?, de modo que al imponerse ambas sanciones de forma cumulativa, dicho elemento resulta doblemente sancionado, sin que dicha reiteración sancionadora pueda justificarse sobre la base de un diferente fundamento punitivo, dado que el bien o interés jurídico protegido por ambas normas es el mismo -la seguridad del tráfico como valor intermedio referencial; la vida e integridad física de todos, como bienes jurídicos referidos. Se trata de un caso en el que el delito absorbe el total contenido de ilicitud de la infracción administrativa, pues el delito añade a dicho elemento común el riesgo para los bienes jurídicos vida e integridad física, inherente a la conducción realizada por una persona con sus facultades psico-físicas disminuidas, debido a la efectiva influencia del alcohol ingerido [F.J. 5. $\left.\left.{ }^{\circ} \mathrm{C}\right)\right] »$.

11 La Ley sobre tráfico, circulación de vehículos a motor y seguridad vial de 1990 establece en su art. 74: «Actuaciones administrativas y jurisdiccionales penales.- 1 . Cuando en un procedimiento administrativo de carácter sancionador se ponga de manifiesto un hecho que ofrezca apariencia de delito o falta perseguible de oficio, la autoridad administrativa lo pondrá en conocimiento del Ministerio Fiscal, por si hubiere lugar al ejercicio de la acción penal. 2. En el caso a que se refiere el apartado anterior no se ordenará la suspensión de las actuaciones del procedimiento administrativo que continuará tramitándose hasta el momento en que el procedimiento esté pendiente de resolución en que se acordará la suspensión. 3. Concluido el proceso penal con sentencia condenatoria de los inculpados, y acordada que hubiere sido la suspensión del procedimiento administrativo, se archivará este procedimiento sin declaración de responsabilidad. Si la sentencia fuera absolutoria o el procedimiento penal acabare por otra resolución que le ponga fin sin declaración de responsabilidad y no estuviera fundada en la inexistencia del hecho, se dictará la resolución que corresponda en el procedimiento administrativo". En el artículo 65 se hace referencia también a dar cuenta de los hechos al Ministerio Fiscal cuando los mismos puedan ser constitutivos de delitos o faltas tipificadas en las leyes penales.
} 
Estamos ante una ley penal en blanco por lo que hay que recurrir a la legislación administrativa para conocer lo que es vehículo de motor o ciclomotor ${ }^{12}$, así como lo que ha de entenderse por vía urbana o interurbana ${ }^{13}$.

Se castiga el mero hecho de conducir con el exceso de velocidad indicada; no se exige la creación de un peligro. No importa que en ese momento la vía esté despejada, por ausencia total de tráfico.

El mero hecho de conducir a velocidad excesiva no debe ser objeto sin más de sanción penal, pues ello también se contempla en la legislación administrativa ${ }^{14}$. Hay que pensar que el legislador presume que en todos estos supuestos existe un peligro abstracto; esto no es correcto, pues aunque pueda ser cierto en unos casos en otros se puede conducir correctamente. Otra cosa es que si conducir a velocidad excesiva se hace con temeridad manifiesta y se pone en concreto peligro la vida o la integridad de las personas se aplicará en art. 380.1, y si concurre manifiesto desprecio por la vida de los demás será de aplicación el art. $381.1^{15}$.

Considerando que el conductor de un vehículo puede incurrir en el error de no saber cuál es el límite máximo de velocidad permitido por la vía que conduce, la administración debe establecerla con claridad en todos los lugares donde fuere necesario con las señales co-

12 Sobre lo que ha de entenderse por vehículo de motor el Anexo II del Reglamento de Vehículos (Real Decreto 2.822/1998, de 23 de diciembre), recoge: «Vehículo de motor: vehículo provisto de motor para su propulsión. Se excluyen de esta definición los ciclomotores, los tranvías y los vehículos para personas de movilidad reducida». A continuación. Sobre las diversas clases de ciclomotores vid anexo I.7 de la Ley de Tráfico (Real Decreto Legislativo 339/1990, de 29 de marzo), y anexo II del Reglamento de Vehículos (Real Decreto 2.822/1998, de 23 de diciembre).

13 La Ley de Tráfico de 1990 en su Anexo II recoge: «76. Via interurbana.- Es toda vía pública situada fuera de poblado; vía urbana.- es toda vía pública situada dentro de poblado excepto las travesías".

14 El art. 65.5,c) de la Ley de tráfico, contempla como infracción muy grave, cuando no sea constitutiva de delito: «Sobrepasar en más de un 50 por 100 la velocidad máxima autorizada, siempre que ello suponga superar, al menos, en 30 kilómetros por hora dicha límite máximo». En el punto 6, del anexo II de la Ley, esta infracción lleva aparejada la pérdida de seis puntos para el titular del permiso o licencia de conducir.

15 La Consulta de la Fiscalía General del Estado 1/2006, cit.; hace referencia a la conducción de vehículos a 200 kilómetros hora e incluso entre 224 y 245 , siendo el límite de velocidad 120. La Consulta se ocupa de estos excesos de velocidad en los delitos de conducción temeraria, y aquellos supuestos en que se pusiera en concreto peligro la vida o la integridad de las personas, o se condujere con desprecio por la vida de los demás. La primera de las conclusiones recoge: «La detección de vehículos a motor circulando a velocidad extremadamente elevada y, significadamente, cuando sobrepase el doble de la máxima autorizada reglamentariamente como sucede en el supuesto sometido a consulta, puede resultar indiciaria de la comisión de un delito contra la seguridad del tráfico del artículo $381 \mathrm{CP}$ ». 
rrespondientes. A este respecto la Disposición Adicional primera de la LO 15/2007 que modifica el Código penal en materia de seguridad vial hace referencia a ello ${ }^{16}$.

\section{CONDUCCIÓN BAJO LA INFLUENCIA DE DROGAS TÓXICAS O BEBIDAS ALCOHÓLICAS.}

Se castiga en el inciso primero del art. 379.2 al «que condujere un vehículo de motor o ciclomotor bajo la influencia de drogas tóxicas, estupefacientes, sustancias psicotrópicas o de bebidas alcohólicas».

Pena: La misma que en el supuesto anterior: prisión de tres a seis meses o multa de seis a doce meses y trabajos en beneficio de la comunidad de treinta y uno a noventa días y en cualquier caso, a la privación del derecho a conducir vehículos a motor y ciclomotores por tiempo superior a uno y hasta cuatro años.

Estas conductas suponen una agravación con respecto al texto anterior (art. 379), pues la pena de trabajos en beneficio de la comunidad no era obligatoria como ahora, sino potestativa del juez.

El bien jurídico protegido es la seguridad vial. Pretende el legislador evitar los riesgos que para la vida o la integridad física de las personas supone la violación de las normas sobre circulación de vehículos y seguridad vial.

El sujeto activo del delito es quien conduce un vehículo de motor bajo la influencia de los efectos del alcohol, drogas tóxicas, estupefacientes o sustancias psicotrópicas. El sujeto pasivo es la colectividad.

Con respecto a lo que haya de entenderse por drogas tóxicas, estupefacientes o sustancias psicotrópicas me remito a lo que establece el Código penal en su artículo $368^{17}$.

El Reglamento General de Circulación hace referencia a estupefacientes, psicotrópicos, estimulantes $\mathrm{u}$ otras circunstancias análogas ${ }^{18}$.

16 La Disposición Adicional de la LO 15/2007, de 30 de noviembre recoge: «Revisión de la señalización vial y de la normativa reguladora de los límites de velocidad. El Gobierno impulsará, de acuerdo con las administraciones competentes, una revisión de la señalización vial y de la normativa reguladora de los límites de velocidad, para adecuar los mismos a las exigencias derivadas de una mayor seguridad vial».

17 Vid. Serrano Gómez, A. y Serrano Maíllo, A., Derecho penal, parte especial, Madrid, 2007, págs. 698 y ss.

${ }_{18}$ El RD 1428/2003, de 21 de noviembre, por el que se aprueba el Reglamento General de Circulación, para la aplicación y desarrollo del texto articulado de la Ley sobre Tráfico, circulación de vehículos a motor y seguridad vial de 1990, recoge en su 
Lo normal es que conducir en tales condiciones lleve a producir un riesgo, aunque no siempre ocurre ${ }^{19}$. Es decisivo que se conduzca "bajo la influencia» de tales sustancias, y necesariamente ha de conllevar un riesgo o peligro abstracto para la seguridad vial ${ }^{20}$. El legislador recoge el riesgo de forma expresa en otros supuestos, con términos como "peligro» (art. 381) y "grave riesgo" (art. 382).

Por «influencia» hay que entender lo que afecta a algo, que en este caso sería negativamente a las condiciones físicas y psíquicas del conductor de un vehículo ${ }^{21}$; ha de estar influido de forma negativa, es decir, restando seguridad a su capacidad para conducir ${ }^{22}$. No sería punible la conducta de quien ha tomado tales sustancias pero que no le afectan a su capacidad para conducir correctamente. Nos encontramos una vez más ante los problemas de prueba en Derecho penal, cuya carga, como es obvio, corresponde a la acusación ${ }^{23}$.

art. 27: «Estupefacientes, psicotrópicos, estimulantes $u$ otras sustancias análogas. 1. No podrán circular por las vías objeto de la legislación sobre tráfico, circulación de vehículos a motor y seguridad vial los conductores de vehículos o bicicletas que hayan ingerido o incorporado a su organismo psicotrópicos, estimulantes $u$ otras sustancias análogas, entre las que se incluirán, en cualquier caso, los medicamentos u otras sustancias análogas, bajo cuyo efecto se altere el estado físico o mental apropiado para circular sin peligro».

${ }^{19}$ Según la sent. del TS de 25 nov. 1991: «Es preciso, pues, que se conduzca el vehículo de motor con sus facultades significativamente alteradas o disminuidas a consecuencia del consumo de aquéllas. Pero, además, se requiere que de aquella conducción se derive una lesión al bien jurídico, que es objeto de protección en el tipo que se examina, esto es, la seguridad del tráfico. De tal forma que si no se pone en peligro concreto bienes jurídicos, no surgiría a la vida aquél». "No basta el dato objetivo del grado de impregnación alcohólica, sino que es preciso acreditar la influencia que la misma tenga en la conducción, no siendo necesario un peligro concreto sino únicamente que la «conducción» estuvo «influenciada por el alcohol»» (sent. de 15 de ab. 2003).

20 Vid. De Vicente Martínez, $R$, «El delito de conducción bajo la influencia de drogas tóxicas, estupefacientes, sustancias psicotrópicas o bebidas alcohólicas y su propuesta de reforma. La cuestionable necesidad de modificar el artículo 379 del Código penal", en La Ley, 16 de febrero 2007, págs. 1 y ss.

${ }_{21}$ Rodríguez Devesa, J.M., en Rodríguez Devesa y Serrano Gómez, Derecho penal español. Parte especial, Madrid, 1995, pág. 1049, dice con respecto a la «influencia» que «basta que repercuta en sus reflejos y, en general, en su psiquismo, para incurrir en el delito».

22 Caballero Gea, A., Delitos contra la seguridad vial, Madrid, 2008, págs. 103 y ss. Gallego SolER, J.I., "El nuevo delito de conducción bajo los efectos del alcohol y las drogas (art. 379.2 CP)", en Seguridad vial y derecho penal, cit., págs. 173 y ss. GómEZ Pavón, P., El delito de conducción bajo la influencia de bebidas alcohólicas, drogas tóxicas o estupefacientes, Barcelona, 1993, págs. 39 y ss.

${ }^{23}$ Recoge la sent. del TC 319/2006, de 15 nov.: "La constatación de tal vacío probatorio, cuya carga corresponde obviamente a la acusación, lleva a concluir que en este caso, de acuerdo con la doctrina constitucional de la que se ha dejado constancia 
Estamos ante un tipo penal con gran inseguridad jurídica, que se desprende de la frase «conducir bajo los efectos». ¿Cuáles son los efectos?, la euforia, por ejemplo, puede ser uno de los efectos que no justifica llevar a penalizarla. Hay que entender que en todo caso es necesario que se pruebe la existencia de un peligro abstracto para la seguridad vial ${ }^{24}$; en el preámbulo de la ley que reforma el Código penal se hace referencia al "peligro abstracto", como límite mínimo de este delito ${ }^{25}$. Este peligro ha de probarse que existe, pues de no ser así la sanción tiene que ser administrativa ${ }^{26}$ y no penal. La falta de seguridad jurídica y certeza en el derecho ha llevado a disparidad de criterios por parte de los jueces y tribunales, que ante la misma situación en uno casos condenan y en otros absuelven ${ }^{27}$. La detección de alcohol en un control policial rutinario, si no existe ninguna prueba ex ante de que el conductor ha creado, al menos, un peligro abstracto para la seguridad vial, la infracción debe ser administrativa y no penal. El control de alcoholemia, sin más, aunque sea positivo no es suficiente para que entre en juego el Código penal, pues son necesarias otras pruebas que demuestren que el conductor conducía bajo los efectos del alco-

en el precedente fundamento jurídico, ha resultado vulnerado el derecho a la presunción de inocencia». Vid. infra nota 34.

${ }^{24}$ La Memoria de la Fiscalía General del Estado de 2005 se ocupa en sus págs. 515 y siguientes de los "delitos relativos a la seguridad vial" en su pág. 524 recoge: «La actuación del conductor debe originar un riesgo para los bienes jurídicos protegidos, sin que por contra se exija la puesta en peligro concreto de los mismos, ya que el delito mantiene su configuración de delito de peligro abstracto».

${ }^{25}$ La LO 15/2007 en el párrafo segundo de su preámbulo recoge: «reforma del Código Penal en materia de Seguridad Vial, cuyo contenido básico persigue, de una parte, incrementar el control sobre el riesgo tolerable por la vía de la expresa previsión de excesos de velocidad que se han de tener por peligrosos o de niveles de ingesta alcohólica que hayan de merecer la misma consideración. A partir de esa estimación de fuente de peligro se regulan diferentes grados de conducta injusta, trazando un arco que va desde el peligro abstracto hasta el perceptible desprecio por la vida de los demás, como ya venía haciendo el Código». No obstante, se tipifican conductas en las que no se exige ningún tipo de peligro como sucede en el tipo del art. 379.1

${ }^{26}$ Dispone el art. 65.5,a) de la Ley de tráfico: «Son infracciones muy graves, cuando no sean constitutivas de delito, las siguientes conductas: a) La conducción por las vías objeto de esta Ley habiendo ingerido bebidas alcohólicas con tasas superiores a las que reglamentariamente se establezcan, y, en todo caso la conducción bajo los efectos de estupefacientes, psicotrópicos, estimulantes y cualquier otra sustancia de efectos análogos». Vid anexo II de la Ley, apartados 1 y 2.

27 La Memoria de la Fiscalía General del Estado de 2005, recoge: «Parece muy necesario destacar que sí se constata una falta de la necesaria uniformidad en la calificación del hecho como delito o bien infracción administrativa. En todo caso puede explicarse ello como reflejo de la excesiva divergencia de criterio entre Juzgados, tanto de Instrucción como Penales, y Secciones de la Audiencia, a la hora de la calificación de una conducción etílica como tal, cuando se trata de un control policial preventivo o aleatorio» (pág. 522). 
hol $^{28}$. También hay que tener en cuenta que los efectos del alcohol no son iguales en todas las personas ${ }^{29}$. Para que la conducción sea ilícito penal es necesario que se haya creado un peligro, en otro caso el ilícito es administrativo ${ }^{30}$.

Las pruebas que realizan los agentes que llevan a cabo el control de alcoholemia suelen ser el comportamiento, forma de expresarse, caminar correctamente sin oscilaciones, si la voz es clara o pastosa, olor a alcohol, etc ${ }^{31}$. Con estos síntomas, cuando se detecta alcohol en

${ }^{28}$ En los controles rutinarios de alcoholemia que hace la policía con carácter preventivo, aunque el sujeto lleve una tasa de alcohol superior al que permite la legislación vial, e inferior a 0'60 miligramos por litro en aire expirado o superior al 1'2 gramos por litro en sangre, que se tipifica como delito en el art. 379.2, la infracción debe ser administrativa y no penal. Para que la conducta tenga relevancia penal, quien realiza la prueba de alcoholemia tiene que haber observado que antes de ordenar al conductor que pare el vehículo el mismo conducía de forma que pudiera estar afectado por la ingerencia de alcohol o sustancias estupefacientes, y lo compruebe con posterioridad al realizar la prueba de alcoholemia. Si no ha observado ninguna irregularidad en el comportamiento del conductor la conducta sólo debe sancionarse administrativamente, aunque de las pruebas que realice con posterioridad pueda deducirse que pudo conducir bajo los efectos del alcohol. Ello es así, porque no está probado que su comportamiento había generado un peligro abstracto. La sent. del TC 256/2007, de 17 de diciembre, recoge en su fundamento de derecho cuarto: "Conforme a reiterada jurisprudencia de este Tribunal, el delito tipificado en el art. $379 \mathrm{CP}$ requiere no sólo la presencia de una determinada concentración alcohólica en el conductor, sino además que esta circunstancia influya o se proyecte sobre la conducción. De modo que para subsumir el hecho enjuiciado en el tipo penal no basta comprobar que el conductor ha ingerido alcohol o alguna otra de las sustancias mencionadas en el precepto, sino que, aun cuando resulte acreditada esta circunstancia, es también necesario comprobar su influencia en el conductor».

29 La sentencia de 3 nov. 2007 de la Sección séptima de la Audiencia Provincial de Barcelona, recoge en el primero de sus fundamentos de derecho: « ... las bebidas alcohólicas actúan con diversa intensidad sobre cada individuo, e incluso sobre el mismo individuo según las concretas circunstancias de cada momento».

${ }^{30}$ La sent. del TS de 15 sep. 2006 recoge en el segundo de sus fundamentos de derecho: "Es un criterio jurisprudencial y forense consolidado, que la diferencia entre el ilícito administrativo y el penal, cuando se trata de conducción bajo ingesta alcohólica, radicaba entre otros aspectos, en el carácter meramente formal de la norma administrativa de superar una determinada ingesta alcohólica mediante las oportunas periciales, en tanto que el ilícito penal supera esa trasgresión formal para exigir la acreditación de un peligro real para la seguridad del tráfico, esto es, la influencia en las facultades psicofísicas necesarias para la conducción poniendo en peligro los bienes juridicos protegidos en la norma".

31 Existe un modelo sobre diligencia de síntomas externos que presentan los conductores sospechosos de hacerlo bajo los efectos del alcohol: aspecto externo (heridas, temblores, cansancio, etc), vestidos (desarreglados, olor a alcohol, sucios, etc), rostro (congestionado, pálido, sudoroso, etc.), mirada (ojos velados, apagados, brillantes, etc), pupilas (dilatadas, algo dilatadas, presencia de nistagmos, etc), comportamiento (normal, agresivo, educado, etc), habla (clara, pastosa, etc.), halitosis alcohólica (notorio a distancia, muy fuerte de cerca, etc), expresión verbal (respuestas claras y ló- 
sangre, los jueces prácticamente condenan siempre, aunque alguna sentencia no los considera suficientes ${ }^{32}$. Los jueces deben comprobar en todo caso que la conducción fue bajo los efectos del alcohol, lo que sucede en el acto de la vista oral y se lleva a cabo en base a la declaración y pruebas practicadas por los agentes de la autoridad que conocieron de los hechos ${ }^{33}$.

En pocas ocasiones la jurisprudencia recoge, dentro de los requisitos que se exigen en el art. 379.2, el riesgo para los bienes jurídicos (peligro abstracto). Sí lo hace la sentencia de la Audiencia Provincial de Santa Cruz de Tenerife de 21-9-2007 que en el tercero de sus fundamentos de derecho recoge: «A la vista de la literalidad del artículo 379 del Código Penal y de conformidad con la doctrina del Tribunal Constitucional y jurisprudencia del Tribunal Supremo, para poder

gicas, gritos, expresión normal, etc), deambulación (correcta, con completa estabilidad, titubeante, incapacidad de mantenerse erguido, etc). Sobre esta cuestión CABALLERO GEA, en ob. cit., págs. 102 y ss. hace un extenso estudio jurisprudencial.

32 La sent. de 3-11-2007 de la Sección Séptima de la Audiencia Provincial de Barcelona recoge en el primero de sus fundamentos de derecho: «Es preciso, pues, que se conduzca el vehículo de motor con las facultades significativamente alteradas o disminuidas a consecuencia del consumo de aquéllas, y este hecho en si mismo ya supone una lesión al bien jurídico protegido en cuanto el tipo penal lo es de peligro abstracto; dicha influencia necesita ser acreditada, sin que a tal fin basten los índices puramente alcoholométricos, bien por que se concrete en una conducción objetivamente anómala o irregular como consecuencia del estado de embriaguez, o porque se aprecien síntomas externos reveladores de dicho estado, y, por tanto, de la afectación a las facultades del sujeto". La sentencia de 23-7-2007 de la Sección 16 de la Audiencia Provincial de Madrid, recoge en el tercero de sus fundamentos de derecho: «Los síntomas recogidos por la fuerza actuante no son decisivos para afirmar sin más tal influencia. Además, tales síntomas no fueron corroborados por los agentes de la guardia civil que depusieron en el acto del Juicio Oral los cuales no recordaban realmente nada de los hechos limitándose a ratificar el contenido del atestado en su día levantado. Ninguna otra prueba, salvo la declaración del acusado negando los hechos que se le imputaban, fue practicada en aquel acto. Es cierto que el atestado recoge síntomas tales como rostro ligeramente enrojecido, ojos brillantes, pupilas dilatadas, habla pastosa, halitosis muy fuerte de cerca y demabulación vacilante, pero junto a ellos se expresa también que su comportamiento y su expresión verbal eran normales, y el vestir sin peculiaridades. Si a ello unimos la constitución física del acusado que, según recogieron los agentes, era corpulenta, podemos afirmar que en el mismo había consumido bebidas alcohólicas, como en parte reconoce, pero no podemos concluir sin duda alguna, estimando que tal ingesta influyera de manera determinante en su conducción». El juzgado de lo penal había condenado y la Audiencia Provincial absuelve, aunque fue decisivo que los agentes de la guardia civil que realizaron la prueba de alcoholemia no recordaran en el acto del juicio oral los hechos que habían recogido en su atestado

33 Establece el párrafo primero del art. 741 de la Ley de Enjuiciamiento Criminal: «El Tribunal, apreciando según su conciencia las pruebas practicadas en el juicio, las razones expuestas por la acusación y la defensa y lo manifestado por los mismos procesados, dictará sentencia dentro del término fijado en esta Ley". 
aplicar el tipo penal es necesario acreditar los siguientes elementos: $\left.1 . .^{\circ}\right)$ Que el acusado en el momento de los hechos condujera un vehículo de motor. $2 .^{\circ}$ ) Que hubiera ingerido drogas tóxicas, estupefacientes, sustancias psicotrópicas o bebidas alcohólicas. 3. ${ }^{\circ}$ ) Que la ingesta de dichas sustancias haya influido en sus facultades psíquicas y físicas en relación con sus niveles de percepción y reacción $4 .^{\circ}$ ) Que la concreta conducta del acusado haya significado un indudable riesgo para los bienes jurídicos protegidos (en la vida, la integridad física de las personas, la seguridad del tráfico)».

Teniendo en cuenta la pena que se establece en el Código para estos delitos, la competencia es de los juzgados de lo penal; sus sentencias son recurribles en apelación ante la Audiencia Provincial. Por tanto son pocos los casos que llegan al Tribunal Supremo; ante el Tribunal Constitucional se recurre en amparo en base al principio de presunción de inocencia ${ }^{34}$ garantizado en el art. 24.2 de la Constitución. Por ello, se recurre a las sentencias dictadas en apelación por las Audiencias Provinciales, que con relativa frecuencia se pronuncian en contra de las condenas dictadas por el Juzgado de lo Penal, normalmente absolviendo ${ }^{35}$.

${ }^{34}$ La sent. del TC 319/2006, de 15 de noviembre, recoge en el primero de sus fundamentos de derecho: «El derecho a la presunción de inocencia experimentaría una vulneración si por la acreditación únicamente de uno de los elementos del citado delito -el de que el conductor haya ingerido bebidas alcohólicas- se presumieran realizados los restantes elementos del mismo, pues el delito no se reduce, entre otras posibilidades típicas, al mero dato de que el conductor haya ingerido alcohol, dado que este supuesto delictivo no consiste en la presencia de un determinado grado de impregnación alcohólica, sino en la conducción de un vehículo de motor bajo la influencia de bebidas alcohólicas. La influencia de bebidas alcohólicas constituye un elemento normativo del tipo penal que consecuentemente requiere una valoración del Juez, en la que éste deberá comprobar si en el caso concreto de la conducción estaba afectada por la ingestión del alcohol. De modo que, para subsumir el hecho enjuiciado en el tipo penal, no basta comprobar el grado de impregnación alcohólica en el conductor, sino que, aun cuando resulte acreditada esa circunstancia mediante las pruebas biológicas practicadas con todas las garantías procesales que la Ley exige, es también necesario comprobar su influencia en el conductor, comprobación que naturalmente deberá realizar el juzgador ponderando todos los medios de prueba obrantes en autos que reúnan dichas garantías. Por ello hemos afirmado que la prueba de impregnación alcohólica puede dar lugar, tras ser valorada conjuntamente con otras pruebas, a la condena del conductor del vehículo, pero ni es la única prueba que puede producir esa condena, ni es una prueba imprescindible para su existencia».

35 Caballero Gea, en ob. cit., hace un extenso estudio de la jurisprudencia en los delitos contra la seguridad vial. La sent. de la Sección Tercera de la Audiencia Provincial de Gerona de 8 de noviembre de 2007, absuelve en apelación a quien había sido condenado por un delito del art. 379 del Código penal. Recoge en el segundo de sus fundamentos de derecho: «No puede obtenerse sin duda razonable alguna que el recurrente tenía mermada su capacidad para conducir, pues véase que el propio Juez de lo Penal, en el relato de hechos probados solo tiene por acreditado que el Sr. Andrés, como signo externo, que presentaba 'halitosis alcohólica notoria' que como 
La prueba sobre alcoholemia, aun siendo positiva no es suficiente, pues aunque el sujeto contenga en sangre cantidad superior a la autorizada ${ }^{36}$, es necesario que ejerza "influencia» en su capacidad para conducir. Lo mismo para los supuestos de drogas tóxicas, estupefacientes o sustancias psicotrópicas. Todo ello salvo lo dispuesto en el inciso segundo del apartado 2 del art. 379 , como se verá más adelante.

En este sentido son necesarias otras pruebas. El atestado policial no es suficiente, pues tiene que ser ratificado en el acto del juicio oral que es donde el Juez valora las pruebas ${ }^{37}$. Para poder demostrar la influencia del alcohol en la conducción, cuando se supera la cantidad autorizada, como ya se indicó, se hacen otras pruebas complementarias, como comprobar si el conductor camino correctamente, forma de hablar, etc ${ }^{38}$. Como el conductor tiene derecho a una segunda medición $^{39}$ y a un análisis de sangre ${ }^{40}$, si el agente que hizo la prueba de alcoholemia no le comunica estos derecho la prueba es nula y hay que absolver.

tiene reiteradamente dicho esta Sala es un signo equívoco, no siendo suficiente para afirmar la influencia de la bebida, cuando no se halla acompañado de otros esenciales y patentes, cuales son el habla pastosa, no puesta de manifiesto en este caso, o el caminar vacilante o con movimiento oscilante de la verticalidad, respecto del cual existen dudas razonables originadas por las manifestaciones de los testigos, y que, además, ni siquiera ha dado como probado el Juez de lo Penal, motivos todos ellos que deben dar lugar a la estimación de la impugnación al no existir prueba suficiente para enervar la presunción de inocencia».

36 Vid. infra nota 28.

37 Se absolvió al presunto culpable como consecuencia de no haberse ratificado la policía con respecto a la alcoholemia que dijo haber detectado $(1,69$ gramos), no existiendo prueba suficiente para condenar que pudiera deducirse en el acto de la vista oral (sent. de 30 nov. 1989). También se absolvió en otro supuesto en el que no hubo ratificación en presencia judicial ni en el acto del juicio (sent. de 16 en. 2002).

38 Vid. supra nota 31.

39 Dispone el art. 23 del Reglamento General de Circulación: "Práctica de las pruebas. 1. Si el resultado de la prueba practicada diera un grado de impregnación alcohólica superior a 0,5 gramos de alcohol por litro de sangre, o a 0,25 miligramos de alcohol por litro de aire espirado, o al previsto para determinados conductores en el artículo $20 \%$, aún sin alcanzar estos límites, presentara la persona examinada sintomas evidentes de encontrarse bajo la influencia de bebidas alcohólicas, el agente someterá al interesado, para una mayor garantía y a efecto de contraste, a la práctica de una segunda prueba de detección alcohólica por el aire espirado, mediante un procedimiento similar al que sirvió para efectuar la primera prueba, de lo que habrá de informarle previamente».

40 Según el art. 23.3 del Reglamento General de Circulación se ha de informar a la persona a quien se practica la prueba de alcoholemia el derecho que tiene «a contrastar los resultados obtenidos mediante análisis de sangre, orina u otros análogos, que el personal facultativo del centro médico al que sea trasladado estime más adecuados». 
Hay jurisprudencia con respecto a la ingestión de alcohol, pero apenas existe sobre supuestos en los que se haya probado que una persona conducía bajo la influencia de drogas tóxicas, estupefacientes o sustancias psicotrópicas; aquí, a diferencia de lo que ocurre con el alcohol, resulta mucho más difícil detectar que el sujeto conduce bajo la influencia de aquéllas ${ }^{41}$.

Con respecto a las tasas de alcoholemia se autoriza circular hasta con 0,5 gramos por litro de alcohol en sangre y 0,25 miligramos por litro en aire espirado ${ }^{42}$, reduciéndose a 0,3 gramos y 0 ' 15 miligramos respectivamente para conductores de ciertos vehículos destinados al transporte de mercancías, de viajeros, servicio público, etc. ${ }^{43}$, así como para los conductores durante los dos años siguientes a la obtención del permiso o licencia que les habilita para conducir ${ }^{44}$. Esta tasa de alcoholemia es a efectos administrativos, no obstante, pueden servir como punto de referencia respecto a una posible infracción penal. Según el Reglamento General de Circulación están obligados a someterse a la

${ }^{41}$ El art. 28 del Reglamento General de Circulación establece: «Pruebas para la detección de sustancias estupefacientes, psicotrópicas, estimulantes u otras sustancias análogas.- 1. Las pruebas para la detección de estupefacientes, psicotrópicos, estimulantes u otras sustancias análogas, así como las personas obligadas a su realización, se ajustarán a lo dispuesto en los párrafos siguientes: a) Las pruebas consistirán normalmente en el reconocimiento médico de la persona obligada y en los análisis clínicos que el Médico forense u otro titular experimentado, o personal facultativo del Centro sanitario o Instituto médico al que sea trasladada aquélla, estimen más adecuados. A petición del interesado o por orden de la Autoridad judicial, se podrán repetir las pruebas a efectos de contraste, que podrán consistir en análisis de sangre, orina u otros análogos».

42 Dispone el art. 20 del Reglamento General de Circulación: "Tasas de alcohol en sangre y aire espirado. 1. No podrán circular por las vías objeto de la legislación sobre tráfico, circulación de vehículos a motor y seguridad vial, los conductores de vehículos ni los conductores de bicicletas con una tasa de alcohol en sangre superior a 0,5 gramos por litro, o de alcohol en aire espirado superior a 0,25 miligramos por litro" (párrafo primero).

43 Dispone el párrafo segundo del art. 20 del Reglamento General de Circulación "cuando se trate de vehículos destinados al transporte de mercancías con una masa máxima autorizada superior a 3.500 kilogramos, vehículos destinados al transporte de viajeros de más de nueve plazas, o de servicio público, al transporte escolar y de menores, al de mercancías peligrosas o de servicios de urgencias o transportes especiales, los conductores no podrán hacerlo con una tasa de alcohol en sangre superior a 0,3 gramos por litro, o de alcohol en aire espirado a 0,15 miligramos por litro».

44 Según el párrafo tercero del art. 20 del Reglamento General de Circulación «los conductores de cualquier vehículo no podrán superar la tasa de alcohol en sangre de 0,3 gramos por litro, ni de alcohol en aire espirado de 0,15 miligramos por litro, durante los dos años siguientes a la obtención del permiso o licencia que les habilita para conducir». Dispone el párrafo siguiente: «A estos efectos, sólo se computará la antigüedad de la licencia de conducción cuando se trate de vehículos para los que sea suficiente dicha licencia». 
prueba de alcoholemia los conductores de vehículos y bicicletas e incluso los usuarios de la vía pública cuando se encuentren implicados en un accidente ${ }^{45}$.

Se plantea la cuestión de si comete delito quien conduce con una tasa de alcohol que no supere 0'25 miligramos por litro en aire espirado o 0'5 gramos por litro en sangre, pero que le influye negativamente en sus facultades para conducir. En estos supuestos se comete el delito que aquí se estudia, pues lo decisivo es que el alcohol ejerza influencia ${ }^{46}$. Otra cosa es que la conducta no sea punible debido al error que puede amparar al conductor que desconoce que el alcohol en pequeñas cantidades le afecta en su capacidad para conducir correctamente.

Sólo son punibles las conductas dolosas, en cuanto que el sujeto ha de ser consciente de que conduce bajo los efectos de las bebidas alcohólicas, drogas, etc. Teniendo en cuanta que todo el mundo conoce la prohibición que existe de conducir bajo los efectos de las bebidas alcohólicas, es difícil que exista un error exculpante ${ }^{47}$, aunque es posible, como se apuntó cuando pequeñas cantidades de alcohol pueden influir en algunos conductores. Cabe la concurrencia de la eximente 2. ${ }^{\mathrm{a}}$ del art. $20^{48}$.

\section{CONDUCCIÓN CON EXCESO DE TASA DE ALCOHOLEMIA}

Se castiga en el inciso segundo del art. 379.2 al "que condujere con una tasa de alcohol en aire espirado superior a 0,60 miligramos por litro o con una tasa de alcohol en sangre superior a 1,2 gramos por litro».

45 Dispone el párrafo primero del art. 21 del Reglamento General de Circulación: «Investigación de la alcoholemia. Personas obligadas.- Todos los conductores de vehículos y de bicicletas quedan obligados a someterse a las pruebas que se establezcan para la detección de las posibles intoxicaciones por alcohol. Igualmente quedan obligados los demás usuarios de la vía cuando se hallen implicados en algún accidente de circulación (artículo 12.2, párrafo primero, del texto articulado)".

46 Caballero Gea, ob. cit., págs. 75 y ss. Gómez Pavón, ob. cit., pág. 48, dice que «desde el punto de vista penal, debemos rechazar la fijación de una tasa de alcoholemia ya que la ley no lo exige».

${ }^{47}$ Rodriguez DEvesa, ob. cit., pág. 1050.

48 Vid. Tamarit Sumalla, J.M., en Quintero Olivares (Director) Comentarios a la Parte Especial del Derecho penal, Navarra, 2005, pág. 1452 escribe: «no puede descartarse que un sujeto que no hubiera previsto tener que ponerse al volante de un automóvil beba hasta llegar a un estado de intoxicación plena y en esa estado emprenda la conducción». 
Pena: La misma que en el supuesto anterior: prisión de tres a seis meses o multa de seis a doce meses y trabajos en beneficio de la comunidad de treinta y uno a noventa días y en cualquier caso, a la privación del derecho a conducir vehículos a motor y ciclomotores por tiempo superior a uno y hasta cuatro años.

El artículo 20 del Reglamento General de Circulación recoge: «Tasas de alcohol en sangre y aire espirado. 1. No podrán circular por las vías objeto de la legislación sobre Tráfico, Circulación de Vehículos a Motor y Seguridad Vial, los conductores de vehículos ni los conductores de bicicletas con una tasa de alcohol en sangre superior a 0,5 gramos por litro, o de alcohol en aire superior a 0,25 miligramos por litro». Cuando la tasa de alcohol sea superior a estas cantidades y no supere 1,2 gramos por litro en sangre, ni 0,62 miligramos por litro en aire aspirado, la sanción es administrativa, si no se ha creado peligro para la circulación. No obstante, sea cual fuere la cantidad de alcohol el conductor podrá incurrir en el delito de conducción bajo la influencia de drogas tóxicas o bebidas alcohólicas del art. 379.2 si lo hiciere bajo la influencia de las mismas y creara riesgo para la circulación.

No importa que quien lleva el vehículo con esa elevada cantidad de alcohol le influya en la conducción ${ }^{49}$. Aunque en estos casos lo probable es que se ocasione un peligro para la circulación, puede haber excepciones, lo que cuestiona que se haya incorporado al Código esta figura de delito ${ }^{50}$.

49 Con esta tasa de alcohol en ocasiones se absolvía al conductor si no existía peligro para la seguridad del tráfico. Recoge la Memoria de la Fiscalía General del Estado de 2005 lo que sigue: «Se ha podido constatar que si hay Juzgados de lo Penal o Salas que califican como delito la conducción cuando el nivel de alcohol en sangre es de 0,6 $\mathrm{ml} . /$. de aire (1,2 gr. $/$. de sangre) por el contrario hay algunos otros que absuelven (incluso por vía de apelación) a pesar de un alto índice de $0,9 \mathrm{ml} . / 1$. de aire $(1,8)$. Dichas absoluciones se fundamentan en la ausencia de peligro para la seguridad del tráfico porque el índice no había rebasado los $0,75 \mathrm{ml} . / \mathrm{l}$. de aire $(1,5)$ y ello siguiendo algunas Sentencias del Tribunal Supremo que señalan que a partir de 1,5 la influencia es probable y a partir de 2,0 es segura. Sin embargo, tal posición supone, según estudios de expertos sobre sistemas de detención de alcohol en el organismo, estimar que un consumo de 9 latas de cerveza ( 3 litros) no origina un peligro abstracto para la seguridad del tráfico. No es precisa la prueba pericial que nos determine, tras el consumo de semejante cantidad de bebida, qué grado de incapacidad para conducir nos ha producido en el organismo. Por ello se aprecia, dado que la Jurisprudencia del Tribunal Supremo no ha establecido criterios orientativos de forma uniforme en torno a cuál es el nivel de alcohol peligroso, y por otro lado, su aplicación, por los Jueces de lo Penal, adolece de preocupante unidad de criterio, la necesidad de que, bien por vía legal o bien jurisprudencial, se establezcan ciertos márgenes que atenúen tal situación de inseguridad jurídica para el justiciable y los profesionales del Derecho. Todo ello sin perjuicio de que en cada supuesto concreto deba acreditarse la influencia de las bebidas alcohólicas en la capacidad del sujeto y en la conducción" (pág. 523).

50 Recoge la sent. del TC 319/2006, del 15 de noviembre, en el tercero de sus fundamentos de derecho: «La influencia de la ingesta de alcohol en las facultades psico- 
La Fiscalía General del Estado antes de la reforma del Código exigía que con esas tasas de alcohol en sangre para que la conducta fuera constitutiva de delito debía de acreditarse que tenía efectos en la capacidad psicofísica del conductor ${ }^{51}$.

El legislador se centra en la tasa de alcohol muy elevada. Sin embargo, no contempla los otros supuestos que también afectan a la seguridad vial como son las drogas tóxicas, estupefacientes o sustancias psicotrópicas. Aunque en estos casos existen dificultades para poder valorar la cantidad de los productos consumidos, lo cierto es que los que conducen un vehículo de motor o ciclomotor en tales circunstancias se encuentran frente al derecho penal en mejor situación que los que lo hacen con un alto índice de alcoholemia ${ }^{52}$.

\section{CONDUCCIÓN TEMERARIA}

Se castiga en el párrafo primero del art. 380.1 al «que condujere un vehículo a motor o un ciclomotor con temeridad manifiesta y pusiera en concreto peligro la vida o la integridad de las personas».

\footnotetext{
físicas se sustenta en el estudio sobre la influencia del alcohol en la conducción contenido en la Sentencia del Tribunal Supremo de 22 de febrero de 1989. En la misma, entre otras consideraciones, se indicaba, aludiendo a la tendencia legislativa de otros países, que 'con referencia al individuo medio se considera a efectos médico-legales que a partir de 1,5 (por mil) la influencia del alcoholen la conducción es probable y cierta a partir del $2.0 \%$.

51 En la Instrucción 3/2006, de 3 de julio, sobre criterios de actuación del Ministerio Fiscal para una efectiva persecución de los ilícitos penales relacionados con la circulación de vehículos a motor, recoge en la sexta de sus conclusiones lo que sigue: «En supuestos de alcoholemia detectada con ocasión de controles preventivos las señoras y señores Fiscales ejercitarán la acción penal por delito del artículo 379 del Código Penal, en todo caso, cuando el grado de impregnación alcohólica sea superior a $1,2 \mathrm{~g}$. de alcohol por $1.000 \mathrm{~cm}$ ? de sangre -o 0'60 $\mathrm{mg}$ de alcohol por litro de aire espirado? si bien deberán proponer la práctica de diligencias de prueba que permitan acreditar el efecto de dicha impregnación alcohólica en la capacidad psicofísica para una conducción segura cuando excepcionalmente dicha tasa de alcohol no vaya acompañada de otros indicios de afectación etílica. En supuestos de alcoholemia comprendida entre 0,80 y $1,2 \mathrm{~g}$ de alcohol por $1.000 \mathrm{~cm}$ ? de sangre $-0,40$ y 0,60 mg de alcohol por litro de aire espirado? la acusación dependerá de las circunstancias concurrentes, tales como la existencia de síntomas de embriaguez en el conductor, la conducción peligrosa o descuidada, o el haber provocado un accidente. Con tasas inferiores a $0,80 \mathrm{~g}$ de alcohol por $1.000 \mathrm{~cm}$ ? de sangre $-0,40 \mathrm{~m}$ de alcohol por litro de aire espirado- las señoras y señores Fiscales no ejercitarán la acusación, derivando los hechos a la vía sancionadora administrativa, salvo en aquellos casos singulares en que las circunstancias concurrentes evidencien la influencia del alcohol en la conducción".

52 Vid. Gallego Soler, op. cit., págs. 170 y ss.
} 
Pena: Prisión de seis meses a dos años y privación del derecho a conducir vehículos a motor y ciclomotores por tiempo superior a uno hasta seis años.

Nos encontramos en otro de los supuestos en los que hay que deslindar el ilícito administrativo del ilícito penal ${ }^{53}$, cuestión de la que se ocupa tanto la jurisprudencia ${ }^{54}$ como la Fiscalía del Tribunal Supre$\mathrm{mo}^{55}$.

El bien jurídico protegido es la vida y la integridad física de las personas.

Conducción manifiestamente temeraria. En el art. 380.2 se establece: «A los efectos del presente precepto se reputará manifiestamente temeraria la conducción en la que concurrieren las circunstancias previstas en el apartado primero y en el inciso segundo del apartado segundo del artículo anterior ${ }^{56}$.

53 El art. 65.5,d) de la Ley de tráfico contempla como infracción muy grave, cuando no sea constitutiva de delito: «la conducción manifiestamente temeraria». El art. 380.1 del Código recoge también la temeridad manifiesta, aunque añade que ésta ha de poner en concreto peligro la vida o la integridad de las personas. Por tanto, cuando la conducción sea manifiestamente temeraria será infracción administrativa, y penal cuando ponga en concreto peligro la vida o la integridad de las personas.

${ }^{54}$ La sent. del TS de 1 de abril de 2002 recoge en el tercero de sus fundamentos de derecho: "La conducción temeraria es, en principio un ilícito administrativo del art. 65.5 .2$, c) (hoy 65.5,d) de la Ley de tráfico, circulación de vehículos a motor y seguridad vial tipifica como infracción muy grave. No obstante, cuando la temeridad es manifiesta, es decir, patente, clara y con ella se pone en concreto peligro la vida o la integridad de las personas, el ilícito se convierte en penal y da lugar al delito previsto en el art. $381 \mathrm{CP}$. Conduce temerariamente un vehículo de motor quien incurre en la más grave infracción de las normas de cuidado formalizadas en la Ley de tráfico, circulación de vehículos a motor y seguridad vial. Siendo así, la temeridad que integra la infracción administrativa es, en principio, la misma que la que integra el delito. La diferencia entre una y oro está en que en el delito la temeridad es notoria o evidente para el ciudadano medio $y$, además, crea un peligro efectivo, constatable, para la vida o la integridad física de personas identificadas o concretas, distintas del conductor temerario. No parece pueda ser cuestionado que la forma de conducir del acusado antes de producir el accidente [...] deba ser calificada como temeraria toda vez que, siendo un conductor novel, circuló a 'velocidad excesiva, realizando adelantamientos en lugares prohibidos, obligando a los vehículos que circulaban por el carril contrario a salirse al arcén e incorporándose al carril propio sin tener en cuenta la existencia de los vehículos que por él circulaban, debiendo éstos retirarse al arcén para evitar la colisión».

${ }^{55}$ La Consulta 1/2006 de la Fiscalía General del Estado, cit., recoge en su apartado III: «Como vemos, la nueva redacción del artículo 65 ha introducido el adverbio 'manifiestamente' en relación con el carácter temerario de la conducción, cuando de infracción muy grave se trate, de modo, que en principio, el concepto de conducción manifiestamente temeraria es presupuesto coincidente en la vía sancionadora administrativa y en la penal».

${ }^{56} \mathrm{La}$ Ley de tráfico en su art. $\left.65.5 .^{\circ}, \mathrm{d}\right)$ considera infracción muy grave, cuando no sea constitutiva de delito «la conducción manifiestamente temeraria», que además de 
El legislador delimita lo que ha de entenderse por «conducción manifiestamente temeraria» a los siguientes supuestos: a) conducir a velocidad superior en sesenta kilómetros por hora en vía urbana o en ochenta kilómetros por hora en vía interurbana a la permitida reglamentariamente, y b) conducir con una tasa de alcohol en aire expirado superior a 0'60 miligramos por litro o con una tasa de alcohol en sangre superior a 1'2 gramos por litro.

Consiste la acción en conducir un vehículo de motor o ciclomotor con temeridad manifiesta y, además, se ponga en concreto peligro la vida o integridad de las personas. Temeridad equivale a imprudencia grave, al no observarse el deber objetivo de cuidado exigible ${ }^{57}$. Ha de ser manifiesta, es decir que pueda ser apreciada con facilidad por ter$\operatorname{ceros}^{58}$.

Las normas de circulación prohíben conducir de modo negligente o temerario ${ }^{59} \mathrm{y}$ "manifiestamente temeraria ${ }^{60}$.

Estamos ante un delito de peligro concreto, pues así se especifica en el texto al decir que se "pusiere en concreto peligro la vida o la integridad de las personas».

El riesgo puede ser tanto para terceros ajenos al vehículos, como para los acompañantes del conductor. Si éstos le piden que pare el vehículo para abandonarlo y se niega, puede haber un concurso de delitos del art. 381 con otro de detención ilegal.

La conducta ha de ser dolosa -se trata de un dolo de peligro-, pues el sujeto ha de conocer que conduce de forma temeraria y pone en

la sanción correspondiente lleva consigo la pérdida de seis puntos, de acuerdo con el anexo II. 4 de la Ley. En el art. 77.3 de la Ley, dentro de las medidas cautelares se establece: «Los agentes de la autoridad inmovilizarán el vehículo cuando a su conductor se le pueda imputar la infracción prevista en el artículo 65.5,d) de la presente Ley y lo mantendrá inmovilizado mientras subsista la causa de la infracción".

57 Se consideró conducción temeraria en las sents. de 20 jul. 1983 (no respetar señal de stop), 12 feb. 1985 (adelantar a más velocidad de la permitida y por la derecha), 30 mayo 1986, 9 marzo 1989 (el conductor bajo los efectos de somnolencia invadió la parte izquierda de la calzada chocando de frente con el vehículo que circulaba en dirección contraria) y 10 marzo 1993 (atropello en paso de cebra circulando a velocidad excesiva).

58 Rodríguez Devesa, ob. cit., pág. 1050.

59 Dispone el art. 3 del Reglamento General de Circulación que «se deberá conducir con la diligencia y precaución necesarias para evitar todo daño, propio o ajeno, cuidando de no poner en peligro, tanto al mismo conductor como a los demás ocupantes del vehículo y al resto de los usuarios de la vía. Queda terminantemente prohibido conducir de modo negligente o temerario» (art. 9.2 de la Ley).

60 Vid. supra nota 53. 
peligro la vida o la integridad de las personas. Es suficiente el dolo eventual.

La consumación se produce en el instante en que el sujeto con su forma temeraria de conducir pone en peligro la vida o la integridad de las personas. Aunque se ponga en peligro a varias personas sólo hay un delito.

\section{SUPUESTOS AGRAVADOS DE CONDUCCIÓN TEMERARIA}

La alarma que produjo la aparición de los vulgarmente conocidos por "conductores homicidas» fue el motivo por el que se incorporó en el C.p., en junio de 1989 el art. 340 bis, d) (art. 384 en el Código penal de 1995 y hoy 381 )

a) Conducción con manifiesto desprecio a la vida de los demás poniendo en concreto peligro para la vida o integridad de las personas.

Se castiga en el art. 381.1 al que "con manifiesto desprecio por la vida de los demás, realizare una conducta descrita en el artículo anterior».

Penas: Prisión de dos a cinco años, multa de doce a veinticuatro meses y privación del derecho a conducir vehículos a motor y ciclomotores durante un periodo de seis a diez años.

La pena de prisión resulta excesiva, y también puede serlo la privación del permiso de conducir. En los supuestos más graves de lesiones cometidos por imprudencia grave la pena es prisión de uno a tres años (art. 152.2. ${ }^{\circ}$ ). El homicidio por imprudencia grave se castiga con la pena de prisión de uno a cuatro años (art. 142.1), y cuando el homicidio imprudente se comete utilizando un vehículo a motor o ciclomotor la privación del derecho a conducir los mismos es de uno a seis años (142.2). Para los supuestos de lesiones graves cometidas por imprudencia grave con vehículo de motor o ciclomotor, la privación del derecho a conducir es de uno a cuatro años.

Para incurrir en este delito es necesario: a) conducir con manifiesto desprecio por la vida de los demás y b) poner en concreto peligro la vida o la integridad de las personas.

Estamos ante un delito de peligro concreto. La dificultad estará en la valoración de cuándo se conduce conscientemente despreciando la vida de los demás y a su vez se ponga en peligro la vida o integridad de otras personas. Cabe plantearse si la conducta prevista en el art. 381.1 puede incardinarse en el art. 380 «temeridad manifiesta y pusiere en peligro la vida o la integridad de las personas». En el art. 
381.1 se especifica «con manifiesto desprecio por la vida de los demás». Hay que entender que ello supone un mayor plus de temeridad; el conductor contempla como probable un resultado lesivo, y a pesar de ello sigue su forma de conducir. Podemos estar en algún supuesto ante un delito de lesiones u homicidio por concurrir dolo eventual ${ }^{61}$.

La referencia a «manifiesto desprecio por la vida de los demás» no puede interpretarse, a priori, como tentativa de homicidio o lesiones, por concurrir dolo eventual, pues no siempre el sujeto acepta el resultado lesivo, sino que confía que no se producirá. Por ello esta figura no tiene justificación ${ }^{62}$, ya que tales situaciones pueden llevar a un delito de imprudencia grave con resultado de lesiones (art. 152) u homicidio (art. 142). Si hubo dolo eventual podrá llegar a castigarse como tentativa de homicidio, con pena inferior en uno o dos grados, según el art. 62 , más severa que la prevista en el mismo, con lo que para estos supuestos resulta figura privilegiada, aunque habría que recurrir al art. 8 para resolver el concurso de leyes. La jurisprudencia se ha pronunciado en pocos casos sobre este delito, pues casi todos los procedimientos iniciados se resolvieron por imprudencia temeraria (hoy imprudencia grave $)^{63}$.

b) Conducción con manifiesto desprecio a la vida de los demás sin poner en concreto peligro la vida o la integridad de las personas.

Se castiga en el art. 381.2 a los que condujeren un vehículo a motor o ciclomotor con manifiesto desprecio por la vida de los demás

${ }^{61}$ La sent. del TS de 1 de abril de 2002 recoge en el tercero de sus fundamentos de derecho: «Un más detenido análisis, sin embargo, pone de relieve que ese elemento subjetivo -el consciente desprecio por la vida de los demás- supone una alteración esencial de la estructura de los delitos contra la seguridad del tráfico [...] el tipo subjetivo está constituido por la conciencia y voluntariedad de la infracción de una norma de cuidado relativa al tráfico, a la conducción de un vehículo de motor o a la seguridad vial, pero no por la conciencia y voluntariedad del resultado que eventualmente puede ocasionar aquella infracción mientras que en el delito a que ahora nos referimos el dolo abarca no sólo la infracción de la norma de cuidado sino también el eventual resultado. No de otra forma puede ser interpretado el tipo en cuestión. Si una persona crea, con su forma temeraria de conducir, un concreto peligro para la vida o la integridad de las personas y lo crea con consciente desprecio para estos bienes jurídicos, debe entenderse que se representa y admite la posibilidad de su lesión, puesto que los pone en peligro precisamente porque no los aprecia, representación y consentimiento que obliga a atribuirle, al menos, el dolo que la doctrina y la jurisprudencia denominan eventual, y si, en tal caso, el resultado representado y admitido se produjese, difícilmente se le podría dejar de imputar al autor a título de dolo"s.

62 Vid. Ragués Vallés, R., "Conducción de vehículos con consciente desprecio por la vida de los demás y tentativa de homicidio», en Anuario, 1997, págs. 787 y ss.

63 Según el Diccionario de la Lengua manifiesto es «algo patente, claro» y desprecio es «desestimación, desaire, desdén». 
«cuando no se hubiere puesto en concreto peligro la vida o la integridad de las personas".

Penas: Prisión de uno a dos años, multa de seis a doce meses y privación del derecho a conducir vehículos a motor y ciclomotores durante un periodo de seis meses a diez años.

Teniendo en cuenta la pena que se establece para las lesiones por imprudencia grave, que oscila entre tres y seis meses y uno a tres años (art. 152), la pena privativa de libertad puede ser excesiva. En cuanto a la privación del permiso de conducir, que resulta elevada, en todo caso debió de ser notablemente inferior a la establecida en el apartado primero del art. 381. No hay justificación para imponer la misma pena de privación del derecho a conducir en los dos apartados del artículo.

\section{Comiso}

Establece el art. 381.3 que «el vehículo a motor o ciclomotor utilizado en los hechos previstos en el presente precepto se considerará instrumento del delito a los efectos del artículo 127 de este Código».

El comiso del vehículo sólo comprende los supuestos de los apartados 2 y 3 del art. 381, es decir cuando la conducción del vehículo a motor o ciclomotor se realice con manifiesto desprecio por la vida de los demás, se haya puesto o no en concreto peligro la vida o la integridad de las personas.

\section{CONCURSO}

Dispone el art. 382 que «Cuando con los actos sancionados en los artículos 379, 380 y 381 se ocasionare, además del riesgo prevenido, un resultado lesivo constitutivo de delito, cualquiera que sea su gravedad, los Jueces o Tribunales apreciarán tan sólo la infracción más gravemente penada, aplicando la pena en su mitad superior y condenando, en todo caso, al resarcimiento de la responsabilidad civil que se hubiera originado».

El concurso sólo cabe cuando el resultado lesivo sea constitutivo de delito, excluyéndose las faltas.

La ley contempla supuestos en los que por imprudencia se cause un resultado de muerte o lesiones teniendo que remitirnos a los arts. 142 y 152. Si los resultados fueran dolosos estaríamos ante un concurso de delitos, no alcanzando los beneficios del art. 382 al autor ${ }^{64}$.

${ }^{64}$ Vid. CoRcoy Bidasolo, M., «Homicidio y lesiones en el ámbito del tráfico viario. Problemática concursal entre los delitos contra la seguridad en el tráfico y los resultados lesivos a ellos imputados», en Seguridad vial y derecho penal, cit., págs. 109 y ss. 


\section{NEGATIVA A REALIZAR LA PRUEBA DE ALCOHOLEMIA, DE PRESENCIA DE DROGAS TÓXICAS, ESTUPEFACIENTES Y SUSTANCIAS PSICOTRÓPICAS}

Se castiga en el art. 383 al «conductor que, requerido por un agente de la autoridad, se negare a someterse a las pruebas legalmente establecidas para la comprobación de las tasas de alcoholemia y la presencia de las drogas tóxicas, estupefacientes y sustancias psicotrópicas a que se refieren los artículos anteriores».

Pena: Prisión de seis meses a un año y privación del derecho a conducir vehículos a motor o ciclomotores por tiempo superior a un año y hasta cuatro años.

La pena resulta excesiva si se tiene en cuenta que el delito de conducir bajo los efectos de bebidas alcohólicas tiene menor pena ${ }^{65}$.

Los requisitos que se exigen en el art. 383 son: a) Requerimiento por agente de la autoridad a realizar la prueba de alcoholemia, presencia de drogas tóxicas, etc. que ha de ser claro, y b) Negativa de la persona requerida a efectuar la misma.

El comportamiento del conductor para evitar someterse a las pruebas a las que hace referencia el texto legal, sin que previamente haya sido requerido para ello, no dará lugar a este delito. Sucederá esto con quien hace caso omiso a la señal de los agentes de la autoridad para que detenga el vehículo, dándose a la fuga, cuando aquellos pretendían practicar la prueba de alcoholemia, drogas tóxicas, etc., pero que no lo han requerido en tal sentido. Entiendo que es suficiente la indicación que se haga al conductor para detener el vehículo en los conocidos "controles de alcoholemia" identificados mediante el rótulo correspondiente; la fuga en estos casos dará lugar al delito del art. 383.

Para combatir la negativa a la prueba de alcoholemia, y evitar la impunidad, puede ser suficiente, además de inmovilizar el vehículo ${ }^{66}$, presentar al conductor ante el Juez competente, como es preceptivo $^{67}$. Así las cosas, posiblemente serán muy pocos los que se nieguen a

65 Vid. Fernández BAutista, S., «El delito de negativa a la realización de las pruebas de alcoholemia (art. 383 CP», en Seguridad vial y derecho penal, cit., pág. 196.

${ }_{66}$ Según el art. 25 del Reglamento General de Circulación cuando las pruebas -o análisis en su caso- de alcoholemia fueran positivas el agente podrá proceder a la inmediata inmovilización del vehículo a no ser que pueda hacerse cargo de su conducción otra persona debidamente habilitada. También podrá inmovilizarse en los casos de negativa a efectuar las pruebas de detección alcohólica.

${ }_{67} \mathrm{El}$ art. 24,c) del Reglamento General de Circulación dedica su artículo 24 a las diligencias del agente de la autoridad, estableciendo en su apartado c) que es función de éstos «conducir al sometido a examen, o al que se negase a someterse a las pruebas de detección alcohólica, en los supuestos en que los hechos revistan caracteres delic- 
la prueba de alcoholemia, presencia de drogas tóxicas, etc., pues al final se les practicará; la negativa les creará ciertos perjuicios.

Sobre la posible inconstitucionalidad de este precepto por conculcar el art. 24.2 de la Constitución ${ }^{68}$, en cuanto proclama el derecho «a no declarar contra sí mismos, a no confesarse culpables», se presentaron multitud de recursos por Jueces y Magistrados al antiguo art. 380 (hoy 383). También por considerar que se vulneraba el principio de proporcionalidad de las penas (art. 25.1 de la $\mathrm{CE}$, en relación con los arts. 1.1, 9.3 y 17 de la misma), pues la pena que se establece en el art. 383 es demasiado severa. La Sent. 161/97, del TC de 2 de octubre, declaró constitucional el art. 380 (hoy 383) del C.p..

En los controles rutinarios, o sin indicios, la negativa debe ser objeto de sanción administrativa pero no penal. Si los agentes observan indicios de que el conductor está bajo los efectos del alcohol o sustancias estupefacientes, le llevará a presencia judicial ${ }^{69}$.

En toda la problemática expuesta a veces no será fácil distinguir la negativa a someterse a la prueba y la infracción administrativa.

Cabe plantear el supuesto en el que un conductor ante la sospecha de que va a ser objeto de un control de alcoholemia se da a la fuga. Hay que entender que la conducta sería impune, ya que no ha sido requerido por los agentes de la autoridad para realizarle la prueba ${ }^{70}$. Ello sin perjuicio de que en la huida se cometa un delito ${ }^{71}$.

tivos de conformidad con lo dispuesto en la Ley de Enjuiciamiento Criminal, al juzgado correspondiente a los efectos que procedan».

68 Vid. Martínez Ruiz, J., «La negativa a la prueba de alcoholemia: el artículo 380 del Código penal (Vicisitudes jurisprudenciales de un delito poco afortunado: el artículo 380 CP de 1995)", en $R D P$, núm. 7, págs. 71 y ss. SERRANo Maíllo, M.I., "Observaciones al Código penal de 1995", en III Congreso andaluz de ciencias penales, Puerto de Santa María, 1996, págs. 114 y s.

69 Vid. supra nota 67.

${ }^{70}$ La sent. del TS de 17 julio 2007 contempla un supuesto de huida en el que absuelve. El conductor había sido condenado por darse a la fuga ante un posible control de alcoholemia. Se le condenó por un delito de desobediencia y otro por conducción temeraria El Tribunal Supremo absolvió por el delito de desobediencia, por tratarse de un autoencubrimiento impune. Se recoge en la misma: "La existencia de un derecho a la huida ha sido reivindicada desde algunas posiciones doctrinales, que afirman la ausencia de culpabilidad por no exigibilidad de una conducta distinta, de un comportamiento conforme a la norma. La jurisprudencia de esta Sala, en los casos de huida o elusión de la acción policial de descubrimiento de la participación en hechos punibles viene admitiendo limitadamente el principio del autoencubrimiento impone, como manifestación del más genérico de inexigibillidad de otra conducta, pero constriñéndolo a los casos de mera huida (delitos de desobediencia) con exclusión de las conductas que en la fuga pongan en peligro o lesionen otros bienes jurídicos».

71 La sent. del TC de 17 nov. 2005 en el segundo de sus fundamentos de derecho recoge: «La Jurisprudencia de esta Sala, en lo casos de huida o elusión de la acción policial subsiguiente a la comisión de otro delito, ha venido admitiendo limitada- 
Pese a haberse declarado constitucional por el TC el art. 380 (ahora 383) la realidad es que sigue latente el problema de justicia material en el concurso real de delitos de los arts. 379.2 y 383. En este sentido alguna Audiencia Provincial, resolviendo recurso de apelación interpuesto contra sentencias dictadas por los Jueces de lo penal que condenan por ambas infracciones, en algún caso llegan a absolver por uno de los delitos; se mantiene que al condenar por ambos preceptos se infringe el principio non bis in idem ${ }^{72}$.

Se absolvió por el delito de desobediencia (hoy negativa a someterse a la prueba) cuando el sujeto que se había negado a realizar la prueba de alcoholemia prestaba signos externos que acreditaban que conducía bajo la influencia del alcohol ${ }^{73}$. En la línea de esta última sentencia entendemos que tampoco cometería el delito quien se negare a realizar la prueba de alcoholemia reconociendo que conducía bajo los efectos del alcohol, drogas tóxicas, etc. Resulta excesivo condenar por ambos delitos, por lo que debía derogarse el art. 383 del Código penal.

Concurso delitos.- Si quien conduce un vehículo a motor o un ciclomotor bajo la influencia de drogas tóxicas, estupefacientes, sustancias psicotrópicas o de bebidas alcohólicas se niega a someterse a la prueba de control a la que es requerido por el agente de la autoridad competente para ello, habrá cometido un delito del art. 379.2 y otro del art. 383.

Como el sujeto que se niega a realizar la prueba está bajo los efectos del alcohol, drogas tóxicas, etc, pueden darse diversas situaciones: cabe estimar la atenuante por analogía (art. 21.6. ${ }^{\mathrm{a}}$ ) del art. 21.1. ${ }^{\mathrm{a}}$, en re-

mente el principio del autoencubrimiento impune, como expresión del más genérico de inexigibilidad de otra conducta, pero sólo en casos de mera huida con exclusión de aquellas conductas que en la fuga pongan en peligro o lesionen otros bienes jurídicos».

${ }^{72}$ La sent. de la Audiencia Provincial de Madrid (Sección 16), de 10 oct. 2000 contempla un supuesto en el que el Juzgado de lo Penal condenó por un delito contra la seguridad del tráfico (art. 379) y por conducción del vehículo de motor bajo la influencia de bebidas alcohólicas y un delito de negativa a la práctica de la prueba de alcoholemia previsto y penado en el art. 380 (hoy 383) del CP. Se admite parcialmente el recurso manteniendo la condena por el art. 380 (hoy 383) y absolviendo por el delito del art. 379. Recoge la sentencia que «ambos preceptos protegen el mismo bien jurídico y la condena simultánea por ambos infringe el principio del non bis in idem vulnerando de esa forma el art. 25 de la CE». Vid. CABALLERo GEA, ob. cit., págs. 238 y ss.

${ }^{73}$ La sent. de la Audiencia Provincial de Salamanca de 16 julio 2002 recoge: «De la conexión entre los delitos previstos en los arts. 379 y 380 (hoy 383) del CP deriva que, si los signos externos constituyen, por sí solos, prueba suficiente para acreditar la influencia del alcohol en la conducción, entonces la negativa a la práctica de la prueba de alcoholemia no puede constituir el delito de desobediencia previsto en el art. 380 » (hoy 383). 
lación con el art. 20.2.o Es difícil que concurra la eximente 2.a del art. 20; también podría concurrir la atenuante $1 .^{\mathrm{a}}$ o la $2 .^{\mathrm{a}}$ del art. $21^{74}$. Sin embargo, la influencia de bebidas alcohólicas no puede considerarse como circunstancia modificativa de la responsabilidad criminal en la conducción bajo los efectos de las mismas del art. 379.2, por ser un elemento integrante del tipo penal.

\section{CONDUCIR TRAS LA PÉRDIDA DE VIGENCIA DEL PERMISO O LICENCIA PARA CONDUCIR}

Se castiga en el párrafo primero del art. 384 al «que condujere un vehículo de motor o ciclomotor en los casos de pérdida de vigencia del permiso o licencia por pérdida total de los puntos asignados legalmente».

Pena: Prisión de tres a seis meses o con la multa de doce a veinticuatro meses y trabajos en beneficio de la comunidad de treinta y uno a noventa días.

Hay que recurrir a la legislación administrativa para conocer el baremo de pérdida de puntos ${ }^{75}$ que pueden llevar a la pérdida de vigencia del permiso o licencia ${ }^{76}$.

La administración es la que tendrá que comunicar al conductor de un vehículo de motor o ciclomotor que como consecuencia de una serie de infracciones cometidas ha perdido la vigencia de su permiso o licencia de conducir. Estamos en un supuesto de expansión del Derecho penal, pues por la comisión de infracciones administrativas la conducción de un vehículo puede pasar a ser delito.

${ }^{74}$ La sent. de 5 sep. 2007 de la Sección 16 de la Audiencia Provincial de Madrid, condenó por un delito de desobediencia «concurriendo la atenuante analógica del art. 21.6. ${ }^{\mathrm{a}}$ en relación con los artículos $21.2 .^{\mathrm{a}}$ y $20.2 .^{\mathrm{a}}$, del Código Penal».

75 Vid. arts. 60 y 63 de la Ley de Tráfico (RDL 339/1990, de 2 de marzo) y disposiciones adicionales $1 .^{\mathrm{a}}, 2 .^{\mathrm{a}}, 3 .^{\mathrm{a}}$ y $6 .^{\mathrm{a}}$, y Anexo II . Arts. 39 y 41 . bis del Reglamento General de Conductores ( $R D$ 779/1997, de 30 de mayo).

76 El Reglamento General de Conductores de 30 de mayo de 1997 dedica el título primero a las autorizaciones administrativas para conducir. Se ocupa en su capítulo II del permiso de conducción: clases, condiciones de expedición, obtención y validez, etc. El capítulo III trata de la licencia de conducción, modelos, clases, etc. El capítulo IV trata de las disposiciones comunes aplicables a permisos y licencias. El art. 5 se ocupa de las clases del permiso de conducción que comprende motocicletas, automóviles, etc. El art. $8 .^{\circ}$ se ocupa de las licencias de conducción, recoge: «Para conducir vehículos especiales agrícolas autopropulsados, ciclomotores y coches de minusválidos se exigirá estar en posesión de la correspondiente licencia de conducción salvo que posea el permiso a que se refieren los apartados 7, párrafo primero y 8 del artículo $6 .^{\circ}$ del presente Reglamento". 


\section{CONDUCIR TRAS LA PRIVACIÓN CAUTELAR O DEFINITIVA DEL PERMISO O LICENCIA POR DECISIÓN JUDICIAL}

Se castiga en el inciso primero del párrafo segundo del art. 384 al "que realizare la conducción tras haber sido privado cautelar o definitivamente del permiso o licencia por decisión judicial».

Pena: Prisión de tres a seis meses o con la multa de doce a veinticuatro meses y trabajos en beneficio de la comunidad de treinta y uno a noventa días.

Estas conductas de no estar tipificadas en este precepto podrían perseguirse como delito de desobediencia o quebrantamiento de condena. Ante el posible concurso que pudiera plantearse sería de aplicación preferente el art. 384, por el principio de especialidad ( $\operatorname{art.} 8 .^{\circ} 10^{a}$ del C.p.).

\section{CONDUCIR EN VEHÍCULO SIN HABER OBTENIDO NUNCA PERMISO O LICENCIA.}

Se castiga en el inciso segundo del párrafo segundo del art. 384: "Al que condujere un vehículo de motor o ciclomotor sin haber obtenido nunca permiso o licencia de conducción».

Pena: Prisión de tres a seis meses o con la multa de doce a veinticuatro meses y trabajos en beneficio de la comunidad de treinta y uno a noventa días.

No se contempla la privación del derecho a conducir vehículos a motor y ciclomotores ${ }^{77}$.

Este delito, que desapareció del Código penal en 1994, por las críticas de que fue objeto no tiene justificación que vuelva a tipificarse ${ }^{78}$.

Se trata de una infracción administrativa; otra cosa es que el autor cometa alguno de los delitos previstos en los artículos anteriores, lo

77 Prieto González, H.M., «El delito de conducción sin permiso en la reforma de los delitos contra la seguridad vial», en Seguridad vial y derecho penal cit., en pág. 279 escribe: "Otra cuestión que resulta sorprendente es que el legislador no haya previsto finalmente la pena de privación del derecho a conducir vehículos a motor y ciclomotores que el Proyecto de Ley Orgánica publicado en el BOE de 15 de enero de 2007 sí contemplaba con gran extensión".

${ }^{78}$ En la reforma del Código penal de 8 de abril de 1967 se incorporó el artículo 340 , bis, c), que decía: «Será castigado con la pena de multa de 10.000 a 50.000 pesetas en el condujere por vía pública un vehículo de motor sin haber obtenido el correspondiente permiso". Vid. CASABO RUIZ, J.R., "El permiso de conducción sin habilitación legal», en Delitos contra la seguridad del tráfico y su prevención, Valencia, 1975, págs. 31 y ss. 
que daría lugar a un concurso real. Hay que pensar que su falta de experiencia supone un riesgo para la circulación, aunque ello no indica que existan conductores sin carnet que sean unos grandes expertos, como sucede en algunos supuestos de intrusismo.

\section{CREACIÓN DE GRAVE RIESGO PARA LA CIRCULACIÓN.}

Se castiga en el art. 385 al que originare un grave riesgo para la circulación de alguna de las siguientes formas:

a) «Colocando en la vía obstáculos imprevisibles, derramando sustancias deslizantes o inflamables o mutando, sustrayendo o anulando la señalización o por cualquier otro medio» (art. 385.1. ${ }^{a}$ ).

Pena: Prisión de seis meses a dos años o multa de doce a veinticuatro meses y trabajos en beneficio de la comunidad de diez a cuarenta días.

Es necesario que estas conductas originen un grave riesgo para la circulación, situación que ha de ser valorada por el Juez. En otro caso estaremos ante una infracción administrativa ${ }^{79}$.

b) «No restableciendo la seguridad de la vía, cuando haya obligación de hacerlo" (art. 385.2. ${ }^{\mathrm{a}}$ ).

Pena: Prisión de seis meses a dos años o multa de doce a veinticuatro meses y trabajos en beneficio de la comunidad de diez a cuarenta días.

Como en el supuesto anterior a veces no será fácil distinguir entre la infracción administrativa y la penal ${ }^{80}$.

El que comete el delito previsto en el supuesto primero no tiene la obligación que exige la conducta del segundo, pues por los mismos hechos no se le puede condenar dos veces ${ }^{81}$.

${ }^{79} \mathrm{La}$ Ley de Tráfico en su art. 10.2 establece que «se prohíbe arrojar, depositar o abandonar sobre la vía objetos o materias que puedan entorpecer la libre circulación...». El mismo contenido tiene el art. 4.2 del Reglamento General de Circulación.

${ }^{80}$ La Ley de Tráfico establece en su art. 10.3: «Quienes hubieran creado sobre la vía algún obstáculo o peligro, deberán hacerlo desparecer lo antes posible, adoptando entretanto las medidas necesarias para que pueda ser advertido por los demás usuarios y para que no se dificulte la circulación». El mismo contenido en el art. 5.1 del Reglamento General de Circulación.

81 Vid. supra nota 10. 